\title{
COMPARATIVE INVESTIGATION OF ANTI-INFLAMMATORY NIRGUNDI OIL AND CASTOR OIL BY PHYSICOCHEMICAL, PHYTOCHEMICAL AND CHROMATOGRAPHIC TECHNIQUES
}

\author{
Shraddha Dhanokar*, Mayuri Kale, Anil Kumar Aher and Sonali Gawali \\ NDMVPS College of Pharmacy, Nasik, Maharashtra, India.
}

\begin{abstract}
Nirgundi oil and Castor oil are used in the treatment of inflammation and Rheumatoid Arthritis. Nirgundi oil is obtained from the leaves of the Vitex Negundo Linn., Lamiaceae and Castor oil is extracted from the seeds of Ricinus Communis L., Euphorbiaceae. The formulations containing both oils produce synergistic effect. Nirgundi oil contains Luteolin and Castor oil has Ricinoleic acid which are responsible for the anti-inflammatory action. The study aims to perform physicochemical and phytochemical investigation of the oils available in local market as its standardization parameters for detection of the adulterations in the oil. The results obtained can be utilized as a quality determination tool for marketed oils.
\end{abstract}

Keywords: Nirgundi oil, Castor oil, Luteolin, Ricinoleic acid and inflammation.

\section{INTRODUCTION}

Nirgundi oil is Volatile aromatic oil extracted from Vitex Negundo leaves which is commonly known as Three leaf or Five leaf chaste tree. Castor oil is vegetable oil obtained by pressing seeds of Ricinus Communis that is locally known as Erande. In Ayurveda, both oils are considered as treatment for 'Ammavata' Nirgundi oil is contraindicated in patients who are undergoing medications as Schizophreia, contraceptives and during pregnancy ${ }^{19}$. Castor oil is contraindicated in Patients suffering from Abdominal, intestinal infections and Kidney disorders and also during Pregnancy ${ }^{21}$. The Pharmacological action of different medicinal plant depends on the phytoconstituents it contains. Inflammation is the primary and complex response of the tissue in order to any uncertain physiological and pathological changes. Inflammation occurs due to activation and migration of Leucocytes from the veins to the injured site and releases Cytokines along with Reactive Oxidative and Nitrogen species. In Nirgundi oil, Luteolin acts in reducing inflammation it acts by reducing oxidative stress of the tissue. Luteolin causes decrease in the synthesis of Interleukin- NF
Kappa B which helps in reduction of the Cyclooxygenase $(\mathrm{COX})^{14}$. Ricinoleic acid in Castor oil acts over inflammation by nucleotide binding domain and Leucin rich protein (NALP3) inflasome cells activation in the injured area and reduces histamine secretion 18

\section{MATERIAL AND METHODS}

Sample Collection

Nirgundi oil and castor oil where procured from the local market for analytical study.

\section{Sample Preparation}

Nirgundi oil and Castor oil were solubilized in Ethanol in 1:2 ratio.

\section{Physicochemical and Phytochemical Sample Preparation}

On the ethanolic samples physicochemical parameters and phytochemical tests are carried out.

\section{Chromatographic Sample Preparation}

Oil samples were completely solubilized in Ethanol. Mobile phase used was Toulene: Ethyl Acetate: Formic Acid (6:4:0.3) and 
Toulene: Ethyl Acetate (8.2:0.4) for Nirgundi oil and Castor oil respectively.

\section{RESULTS}

A]Physicochemical standardization

The oils were standardized for physical parameters as Color, Odour, Solubility, Viscosity, Relative density and Refractive index. The Chemical parameters studied are lodine, Saponification, Unsaponification and Acid Values. The observations are mentioned in Table 1.

\section{B] Phytochemical Standardization}

The oils were analyzed for presence of Alkaloids, Carbohydrates, Glycosides, Flavanoids, Phenolics, Steroids and type of oil. Results have been described in Table 2 .

\section{C]Chromatographic Standardization}

Chromatographic analysis of Nirgundi oil and Castor oil was performed. Structure of Luteolin and Ricinoleic acid has been given in Figure 1\&2 respectively. Nirgundi oil showed presence of Luteolin at Rf Value 0.44 as a Dark orange spot. Castor oil contains Ricinoleic acid which is observed at Rf Value 0.27 as a Greenish Yellow Spot. Observed TLC of Nirgundi Oil and Castor Oil has been shown in Figure 3 and Figure 4 respectively.

\section{CONCLUSIONS}

This research work concludes with the standard values of marketed oils. Qualitative analysis helps to determine the Purity of oils. Further HPTLC studies can be carried out for Quantitative analysis. Adulteration of oils can be determined with above mentioned tests.<smiles>O=c1cc(-c2ccc(O)c(O)c2)oc2cc(O)cc(O)c12</smiles>

Fig. 1: Luteolin

3', 4', 5, 7-tetrahydroxyflavone<smiles>CCCCCCCC(O)C/C=C\CCCCCCCC(=O)O</smiles>

Fig. 2: Ricinoleic acid

12-hydroxy-9-cis-octadeconic acid 


\section{DISCUSSIONS}

Table 1: Physicochemical Parameters

\begin{tabular}{|c|c|c|c|}
\hline \multirow{2}{*}{$\begin{array}{c}\text { Sr. } \\
\text { No. }\end{array}$} & \multirow{2}{*}{$\begin{array}{c}\text { Physicochemical } \\
\text { Parameters }\end{array}$} & $\begin{array}{c}\text { Nirgundi } \\
\text { Oil }\end{array}$ & $\begin{array}{c}\text { Result } \\
\text { Oil }\end{array}$ \\
\cline { 3 - 4 } & Plant Part & Leaves & Seeds \\
\hline 2. & Color & $\begin{array}{c}\text { Greenish } \\
\text { Brown }\end{array}$ & Pale yellow \\
\hline 3. & Odour & Aromatic & Faint \\
\hline 4. & Solubility & $\begin{array}{c}\text { Soluble in Ethanol, } \\
\text { Ethyl acetate. }\end{array}$ & $\begin{array}{c}\text { Soluble in Ethanol, Benzene, } \\
\text { Chloroform. }\end{array}$ \\
\hline 5. & Viscosity & 6 Centistoke & 8 Centistoke \\
\hline 6. & Relative density & 0.92 & 0.96 \\
\hline 7. & Refractive index & 1.49 & 1.47 \\
\hline 8. & lodine Value & 124 & 85 \\
\hline 9. & Saponification Value & 148 & 178 \\
\hline 10. & Unsaponification matter & $8.4 \%$ & $0.8 \%$ \\
\hline 11. & Acid Value & 11.9 & 1.4 \\
\hline
\end{tabular}

Table 2: Phytochemical Tests

\begin{tabular}{|c|c|c|c|c|}
\hline \multirow{2}{*}{$\begin{array}{l}\text { Sr. } \\
\text { No. }\end{array}$} & \multirow{2}{*}{ Test } & \multirow{2}{*}{ Observation } & \multicolumn{2}{|c|}{ Result } \\
\hline & & & Nirgundi Oil & Castor Oil \\
\hline 1. & Alkaloids- Wagner's Test & $\begin{array}{l}\text { Reddish brown } \\
\text { Precipitate }\end{array}$ & Negative & Positive \\
\hline 2. & $\begin{array}{c}\text { Carbohydrates- Fehling's } \\
\text { test }\end{array}$ & Brick red precipitate & Positive & Positive \\
\hline 3. & $\begin{array}{c}\text { Anthraquinone Glycosides- } \\
\text { Borntrager's Test }\end{array}$ & $\begin{array}{c}\text { Ammonical } \\
\text { layer appears } \\
\text { Pink }\end{array}$ & Negative & Positive \\
\hline 4. & $\begin{array}{c}\text { Saponin } \\
\text { Glycosides- Foam test }\end{array}$ & $\begin{array}{l}\text { Persistant } \\
\text { Foam }\end{array}$ & Positive & Positive \\
\hline 5. & Flavanoids- Shinoda test & $\begin{array}{l}\text { Reddish } \\
\text { purple color }\end{array}$ & Positive & Positive \\
\hline 6. & $\begin{array}{c}\text { Phenolics- Ferric Chloride } \\
\text { Test }\end{array}$ & $\begin{array}{l}\text { Blue black } \\
\text { Color }\end{array}$ & Negative & Negative \\
\hline 7. & Tannins- Gelatin test & White Precipitate & Positive & Positive \\
\hline 8. & Steroids-Salkowski test & $\begin{array}{l}\text { Chloroform layer } \\
\text { appears red } \\
\text { and acid layer } \\
\text { appears yellow }\end{array}$ & Negative & Negative \\
\hline 9. & $\begin{array}{c}\text { Type of Oil- } \\
\text { Filter Paper test }\end{array}$ & $\begin{array}{l}\text { Stain on filter paper- } \\
\text { Fixed oil is Present }\end{array}$ & $\begin{array}{l}\text { Negative- } \\
\text { Volatile Oil }\end{array}$ & $\begin{array}{l}\text { Positive- } \\
\text { Fixed oil }\end{array}$ \\
\hline
\end{tabular}

Table 3: Chromatographic standardization

\begin{tabular}{|c|c|c|c|c|}
\hline S.No. & Sample & Mobile Phase & Visualization & Rf Value \\
\hline 1. & Nirgundi Oil & $\begin{array}{l}\text { Toulene: Ethyl Acetate: } \\
\text { Formic Acid (6:4:0.3) }\end{array}$ & \multirow{2}{*}{$\begin{array}{c}\text { In UV } \\
\text { Spectrophotometer at } \\
254 \mathrm{~nm} .\end{array}$} & 0.44 \\
\hline 2. & Castor Oil & $\begin{array}{c}\text { Toulene: Ethyl Acetate } \\
(8.2: 0.4)\end{array}$ & & 0.27 \\
\hline
\end{tabular}




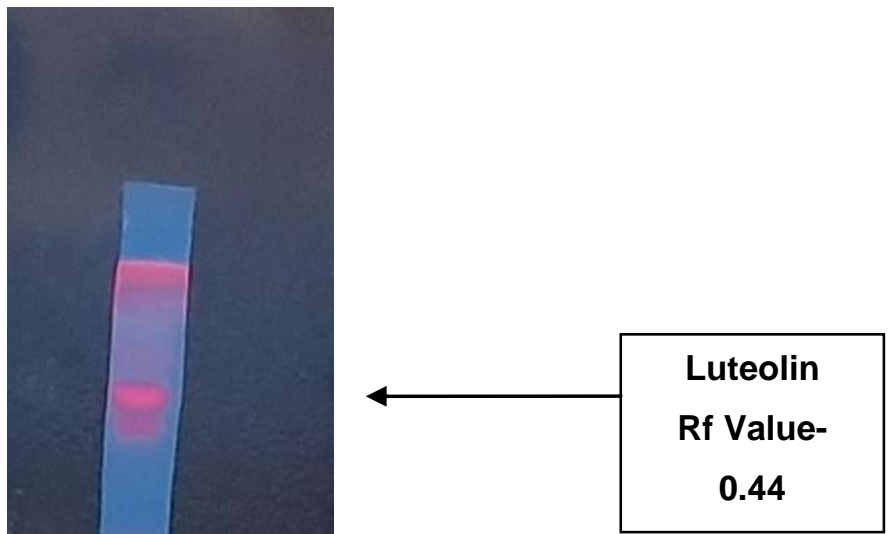

Fig. 3: TLC of Nirgundi Oil

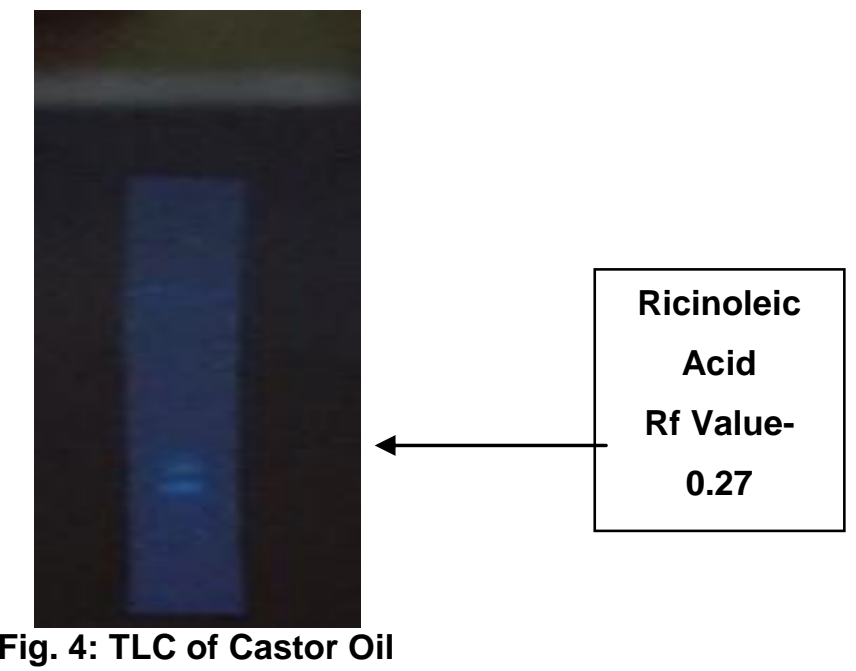

\section{REFERENCES}

1. Khandelwal K, Deore S and Sethi V. Practical Pharmacognosy Techniques and Experiments, Twenty-seventh edition, Nirali Prakashan, Pune. 2014.

2. Kokate C, Gokhale S and Purohit A. Pharmacognosy, Nirali Publications, $51^{\text {st }}$ edition, Pune. 2015.

3. Rangari V. Pharmacognosy \& Phytochemistry, Career publications, $3^{\text {rd }}$ edition, Vol-2, Nasik. 2014.

4. Deore S, Khadbadi S and Baviskar B. Pharmacognosy \& Phytochemistry- a comprehensive PharmaMed Press, Approach, Hyderabad. 2018.
5. Anonymous, The Thin Layer Chromatographic Atlas of Ayurvedic Pharmacopoeial drugs, Part 1, Volume 3, First edition, Government of India, Ministry of AYUSH, and Pharmacopoeia commission for Indian medicine and Homeopathy Publisher, Ghaziabad. 2016.

6. Anonymous. The Ayurvedic Pharmacopoeia of India, Government of India, Ministry of Health and Family Welfare, Department of ISM\&H, Part1 , Volume.

7. Dhale $D$ and Markandeya S. Pharmacognostic and Physicochemical Evaluation of Leaves of Vitex negundo Linn. International 
Journal of Pharma. Research and Development-online. 2010;2(3):1-6.

8. Pathan $M$ and Fatema $S$. Phytochemical and Physiochemical Analysis of Conventional and Microwave Assisted Extraction of Vitex negundo Linn Leaves, Indo American Journal of Pharmaceutical Sciences. 2018;5(6):6057-6065.

9. Patankar A, Nandeshwar $L$ and Pargude S. Standardization of Nirgundi Taila (oil) and its conversion into an ointment. Ayurlog-National Journal of Research in Ayurvedic Science. 2015;3(1):1-9.

10. Panchal H, Amin A, Shah M and Bhatt V. Development of Validated High Performance Thin Layer Chromatography Method For Simultaneous Determination of Apigenin and Luteolin in Achillea Millfolium. Journal of Chemical And Pharmaceutical research. 2017;9(11):39-45.

11. Padmikaran $C$, Prasad $U$ and Kumar S. Analytical Study of Nirgundi Taila, Journal of Biological and Scientific Opinion. 2015;3(3):122-127.

12. Bharthi V, Meghashree $B$, Shantha $T$, Rama R, Shiddamallayya $N$ and Sulochana B. Phytochemical Analysis And Microscopy of Flowers of Vitex Negundo L- Verbenaceae, World Journal of Pharmacy and Pharmaceutical Sciences. 2015;6(4):1852-1862.
13. Shetty D and Patil S. Phytochemical Analysis and Evaluation of Antioxidant Activity of Vitex Negundo seed Extract, International Journal of Pharmacognosy and Phytochemical Research. 2015;7(4):789-792.

14. Lazaro M. Distribution and Biological Activities of Flavanoid Luteolin. Mini Reviews in Medicinal chemistry. 2009;9:31-59.

15. Perez S, Flores $J$ and Perez J. Chemical and Physical properties, Structure, Biological Activity, Uses and Applications of Castor Seeds, Research gate. 2014;250-262.

16. Abdul M, Hajrah N, Sabir S and Garni A. Therapeutic role of Ricinus Communis L. and its bioactive compounds in disease prevention and treatment. Asian Journal of Tropical Medicine. 2019;177-185.

17. Ahmad N, Mishra A, Ashan F and Mahmood T. Ricinus Communis. Pharmacological Actions And Marketed Medicinal Products. World Journal of Pharmaceutical and Life sciences. 2016;2(1):179-188.

18. Patel V, Dumancas G, Vishwanath $K$ and Maples R. Castor oil: Properties, Uses, and optimization of processing parameters in commercial production, Liberates Academia Freedom Research. 2016;9:1-12.

19. Ahuja C, Ahuja $S$, Ahuja $U$ and Nirgundi (Vitexnegundo). Nature's Gift Mankind, Asian Agri-History. 2015;19(1):5-32. 